\title{
Creating A Standardized Test For The Vocational High School English Final Examination: An Alternative
}

\author{
Ashadi \\ State University of Yogyakarta
}

\begin{abstract}
The final examination has a significant impact on all stakeholders in corresponding education. It has become a general measurement of success among them and the results reflect the students' and teachers' performance. The ministry of education has selected TOEIC as the vocational high school English final examination in response to the implementation of the Competency-Based Curriculum since 2004. The last two trials of the examinations created a lot of controversies both in the number of failures and their implications to scoring system.

This article conveys reasonable objections to the adoption of international wide scale testing to the English education in Indonesia. Several issues will be addressed to the concem which leads to these failures including the decision to apply TOEIC to measure students' language competencies, the ethical issues in language testing, validity and reliability. These all lead to further idea of the construction of a good standardized English test as high school English final examination.
\end{abstract}

Keywords: stakeholders, TOEIC, competencies, standardized test, ethical issues

\section{Introduction}

The fact that almost $30.69 \%$ high school students failed in their final examination of academic year 2004/2005 really becomes a deep concern. Despite few other subjects, English becomes the most contributive to the number of failed test participants. A comprehensible answer must be found to deal with the 
problems objectively and to provide best solution that helps parties involved in the phenomenon. An empirical and experimental research on this phenomenon might suit well to see the problem independently in details.

The recently applied school based curriculum (KTSP) and the previous competence based curriculum (CBC) have led to the application of the Test of English for International Communication (TOEIC) for vocational high school students. Therefore, to assess students' English competencies, TOEIC, is administered. The minister of national education, especially the Director General of Elementary and Senior Education urged for an enhancement in students' language competencies. Vocational high school students are expected to be able to possess certain competency standards after graduation, though they do not continue their study at the university level. Here lies the missing link between students' expected competencies and the application of TOEIC as a part of the final examination.

This paper tries to propose a construction of a standardized English test for vocational high school final examination that can actually measure students' communicative competencies. A mere validity study on the TOEIC for vocational high schools will not be sufficient to address the complexity of the problems as it will only result in descriptive conclusion whether the TOEIC implementation is valid and reliable enough.

Besides, this paper attempts to empower test takers, local teachers and language researchers to free themselves from being colonialized by western capital. as suggested by Shohamy (1997: p.2):

"Tests represent a social technology deeply embedded in education, government and business; as such they provide the mechanism for enforcing power and control. Tests are most powerful as they are often the single indicators for determining the future of individuals."

Further she adds that large-scale testing is not an unbiased process, but rather is the "agent of cultural, social, political, educational, and ideological agendas that shape the lives of individual participants, teachers and learners." (p.3)

Therefore this paper offers more than just an idea as it attempts to see the overall problems appearing in vocational high school English final examination. 
The offer is hopefully beneficial and constructive for the government (policy makers), the vocational high school teachers and students as well as English language testing world in general. A further step is expected as a follow up of this discourse so that the offer becomes effective.

\section{Discussion}

In line with the rationale above, this paper identifies four main problems, which are as follow (1) the students' failure might be caused by incongruity of TOEIC with the teaching/learning processes (2) the competence based vocational high school curriculum provides unclear directions for the construction of the test, (3) a good standardized test is required to really measure the competencies as stated in the curriculum (and to replace TOEIC for some considerations) (4) the standardized test will result in standardized scores that should be able to serve as real standards of students' graduation, proficiency, prediction and competence.

In order to reach these specified areas, this paper will only deal with some major constructs as indicated by the title. Firstly this paper will discuss the strengths and weaknesses of the currently applied test as vocational high school English final examination that is TOEIC. There have been a lot of studies on its -validity and reliability in various countries. Thus evidences on some validation test results on TOEIC are required before making further judgment on it.

The discussion will also focus on English final examination for vocational high schools. Hence the application of Competency Based Curriculum applied in trials also needs to be discussed and reviewed. The other concepts that plays important role in this study is the term standardized test itself which is relatively complex in its implementation.

This paper aims (1) to provide empirical evidences in previous researches that TOEIC is not a good measure of communicative competence, (2) to determine the elements/skills of language should be tested in Vocational High School final exam related to the competences stated in Competence Based Curriculum, and (3) to see the possibility of constructing a good, valid, reliable and fair standardized test as vocational High school English final examination. 
Some benefits might accompany the discussion in this sensitive area. It can offer new insights for high school educational stakeholders' different from colonization of western capital (buying expensive testing programs means a lot of money flows out of the country). It helps them to see the implementation of vocational high school final examination from various aspects. This paper also provides the stakeholders with the possibility of constructing a standardized test of English suitable with the goals stated in the curriculum. Teachers can also get benefit from this paper in order to maintain the improvement and quality of the test as well as the teaching. Besides, it serves an invitation to local experts to contribute in the discussion of standardized language testing which can be of our own.

\section{A. The Test of English for International Communication (TOEIC)}

Tests of validity and reliability are required to verify the high standard of a test. Validity according to Heaton $(1975,1975)$ is that the test should measure what it is intended to measure and nothing else and it can not be valid unless it is reliable as a measuring instrument. Early indication in this matter arises from teachers' opinions on the suitability of this kind of test to be applied in final examination for some schools do not have complete equipments to support the test implementation. Besides, according to some related teachers, many of the students are not familiar with this kind of test. If it is so, eventually, the test can not be said to have face validity (Heaton, 1975: 153).

As subjective judgments should be avoided in academic world, other theoretical reviews and empirical evidences are presented to figure out the real proble $n$. Still other validity tests need to be conducted for content and construct validity play important roles in test evaluations. According to Brown (2001: p. 388) content validity can be claimed if a test actually samples the subject matter about which conclusions are to be drawn and construct validity refers to whether the test actually tap into the theoretical construct as it has been defined.

External validity that consists of concurrent and predictive validity will also be important to compare TOEIC and other forms of tests. Concurrent validation involves the comparison of the test scores with some other measure for the same candidate taken at roughly the same time. Predictive validity measures how a candidate will perform in the future by using a correlation between scores of two tests for each candidate. Candidates with high score of TOEIC are supposed to perform better in further study or at work. Thus, the implementation of TOEIC for 
vocational high school final examination is still questionable in terms of validity, reliability and utility.

The Test of English for International Communication (the TOEIC) is a multiple-choice proficiency test of listening and reading skills. Educational Testing Services (ETS) and the Chauncey Group International Ltd., the developers and administrators of the TOEIC program, describe the test as a direct measure of those abilities and as an indirect measure of speaking and writing. They also claim a strong correlation between TOEIC scores and English communicative abilities (TOEIC Examinee Handbook 1996). Yet as the format includes neither a spoken nor a written discourse component, some feel that the claim can be misleading for if misinterpreted by test users.

A study held by Cunningham (2002: 66) concludes that TOEIC should not be used to determine communicative abilities and it should not be sold as a measure of these abilities. Her findings are: (1) TOEIC scores do not imply students' communicative competence. (2) There is no positive correlation between TOEIC score gains and increased communicative competence. (3) A TOEIC testpreparation course does not necessarily result in improved structural competence during language use (4) the more predominant type of errors made by the students are lexical rather than syntactic.

Though TOEIC content and face validities for the reading and listening ability are high, the same can not be said for speaking and writing ability. It also shows high reliability and faimess but only with regard to the measurement of language receptive skills (Moritoshi, 2001: 16-17).

\section{B. Communicative Competence}

Education Assessment Center of National -Education Department has provided competencies standard to be achieved by vocational high school English teaching. These can be guidelines in this study to establish a good construct for communicative competences. They are: (1) Students are able to understand oral text in forms of sentences, conversations, narratives and description by determining specific information, general description, implied/explicit information and translate meaning on context. (2) Students are able to understand oral text by determining pictures. (3) Students are able to understand narrative, expository, descriptive, argumentative, instructive texts by determining specific 
information, general description, implied/explicit information by translating the meaning of words, phrases, and sentences based on contexts. (4) Students are able to understand graphs, tables, diagrams. Maps, forms, agendas, diaries and advertisement by determining specific information, general description, implied/explicit information by translating the meaning of words, phrases, and sentences based on contexts. (5) Students are able to write a united paragraph by arranging random sentences, completing simple letters, incomplete conversations and texts by using relevant language elements.

Communication has been a goal of second language teaching and testing for many times and in many places and communicative competence is no longer new as a term, it is not entirely new either as a concept as well. Experts encourage language classrooms to center on teaching communicative competence and argue that focusing on form over the potential of language in use is irrelevant if the end result is knowledge that can neither be accessed nor applied in communication. The complexity of defining an approach to communicative competence in the classroom has resulted in test-developers creating 'communicative' tests that demonstrate themselves in the accessories of traditional testing paradigms.

Canale and Swain (1980) propose four components of communicative competence in a theoretical framework for curriculum and evaluation. They are identified as grammatical competence, sociolinguistics competence, discourse competence, and strategic competence, which often been referred to in communicative language teaching studies. If we refer to the above standards, only grammatical, socio-linguistics and discourse competence are referred at this stage of education as students are not expected to master verbal and non verbal communication strategic.

\section{C.Standardized Test}

The value and quality of a test are dependent on practical considerations so practicality is the main issue in standardized tests. The practicality covers financial limitations, time constraints, ease of administration, scoring and interpretation. A standardized test must have fixed predetermined responses in a format and it is intended to be administered to large audiences with results quickly distributed to test takers. It is normally norm-referenced as each score is interpreted in relation to mean, median, standard deviation, and/or percentile rank (Brown, 2001: 386). 
Hopkins and Richard (1979: 151) defines standardized test as a commercially printed test for which content has been selected and checked empirically. The test is standardized so that administration and scoring procedures are the same for all test takers. Score interpretation is made to averages of performances of groups of test takers whose scores are then used for making comparison to interpret obtained scores. Scoring standardized tests has, at least, two purposes, namely completing the scoring accurately and completing the task as soon as possible.

Language testing in Indonesia still lacks any agreed standards by which language tests can be evaluated, compared or selected. The need for such standards is often discussed but due to limitation reason, the authority prefers to use the internationally available tests. Language testing theory has already set of principles which can facilitate such test construction and research. These principles are in forms of validity, reliability, faimess and practicality that have been discussed in section II. A.

It is not an easy task to construct a standardized test, but the construction will be worth of improvements in many areas of language education. The standardized test to be constructed is specific for vocational high school final examination; hence it must measure the pre-stated goals in the curriculum. As we see in section II. B., Education Assessment Center of National Education Department has provided competence standards to be achieved by vocational high school English teaching. Thus, the construction of the test must follow the predetermined goals of competence as a requirement of construct validity.

\section{Conclusion}

This paper is an offer, but it is also an invitation for any interested parties to contribute in the development of language testing in Indonesia especially and English education in general. The idea may be hard to carry out but it is still great possibility to realize. The underlying principles are to assist the marginalized vocational high school students, teachers and authorities in addressing the problems occurring in the English final examination. Yet, it is also a challenge for local experts in English language testing to prove themselves. If it is realized, it can be a long and complicated project but it is worth education improvement to certain extent. 
The effort to construct a standardized English test for vocational high school is also a response to ethical language testing which sticks on globally widescale tests such as TOEIC and TOEFL. There has been a growing consciousness that wide scale testing can have consequences beyond just the classroom. Tests and test results have a significant impact on the career or life chances of individual test takers (e.g. access to educational/employment opportunities). They also influence on educational systems and on society more widely: for example, test results are used to make decisions about school curriculum planning, immigration policy, or professional registration for doctors; and the development of a test may lead publishers and institutions to produce test preparation materials and run test preparation courses (business perspective).

Critical testing implies the need to develop critical strategies to examine the uses and consequences of tests, to monitor their power, minimize their detri-mental force, reveal the misuses, and empower the test takers. (Shohamy, 2001,p. 131)

English taught in the vocational high school education is slightly different from general English. The teaching methods, objectives and activities are not aimed to increase students' scores for the wide scale tests but to achieve certain 'communicative' competence pre-determined in the applied Competence Based Curriculum. Thus, the implementation of such tests as final examination seems to have unfavorable/harmful wash back effect on teaching-learning process. This paper, therefore, suggests the strict use of competence standards as guidelines in constructing the proposed standardized /English test as vocational high school final examination.

Since this paper is merely an offer especially to English language education in Indonesia, further steps of validation studies or empirical and experimental researches on this particular area might bolster the realization of a standardized English test construction for vocational high school final examination. Vocational high school English teachers or language testing experts can follow up this issue with various relevant studies so that more data and evidences can facilitate the construction of the standardized test. 


\section{Bibliography}

Brown, Douglas H. 2001. Teaching by Principles: An Interactive Approach to Language Pedagogy. Longman: New York.

Brumfit, C.J. and K. Johnson (eds.) (1979). The Communicative Approach to Language Teaching. Oxford University Press.

Canale, M. (1983). From Communicative Competence to Communicative Language Pedagogy. In Richards in Schmitt (eds.) pages 2-27.

Canale, M. and M. Swain (1980) "Theoretical bases of Communicative Approaches to second language teaching and testing." Applied Linguistics 1:1-47

Cunningham, Cynthia R. 2002. The TOEIC test Communicative Competence: Do Test Score Gains Correlate With Increased Competence? a preliminary study. Dissertation in the School of Humanities: University of Birmingham

Heaton, J.B. 1975. Writing English Language Test: A Practical Guide for Teachers of English as a Foreign Language. Longman: London.

Moritoshi, Paul. 2001. Test of English for International Communication (TOEIC): necessity, proficiency level, test score utilization and accuracy. University of Birmingham.

Shohamy, Elana. March 1997. Critical Language Testing and Beyond. Paper delivered at the American Association of Applied Linguistics, Orlando, FL.

Shohamy, Elana. 2001.The Power of Test: A Critical Perspective on the Use of Language Tests. Harlow: Longman/Pearson

Surapranata, Sumarna, Dr. Analisis, Validitas, Reliabilitas dan Interpretasi Hasil Tes Implementasi Kurikulum 2004. Bandung: PT. Remaja Rosdakarya.

Pusat Kurikulum,Badan Penelitian dan Pengembangan Departemen Pendidikan Nasional Pelayanan Profesional Kurikulum 2004. 2003. Kurikulum Berbasis Kompetensi. Jakarta: Pusat KurikuIum,Balitbang Depdiknas

http://www.kompas.com/kompas-cetak/0406/11/humaniora/1077139/htm. Hasil UAN di Umumkan Hari Ini. Retrieved on November 18th, 2005. 